\title{
Association of cotton leaf curl Gezira virus with tomato leaf curl betasatellite infecting Carica papaya in Iran
}

\author{
Kaveh Bananej ${ }^{1} \cdot$ Muhammad Shafiq $^{2} \cdot$ Muhammad Shafiq Shahid $^{2}$
}

Received: 15 November 2020 / Accepted: 17 January 2021 / Published online: 27 February 2021

(c) Australasian Plant Pathology Society Inc. 2021

\begin{abstract}
Papaya leaves exhibiting severe leaf curling and stunting symptoms were tested for the presence of begomovirus infection. The putative full-length cotton leaf curl Gezira virus (CLCuGV) and tomato leaf curl betasatellite (ToLCB) molecules were amplified, sequenced and analyzed. This is the first study providing the identification of CLCuGeV and ToLCB infecting papaya in Iran.
\end{abstract}

Keywords Geminiviridae: begomovirus · Cotton leaf curl gezira virus · Tomato leaf curl betasatellite · Carica papaya

Plant infecting viruses of the family Geminiviridae are consisting of circular, single-stranded DNA (ssDNA) molecules. Geminiviruses are currently divided into nine genera based on insect vector, genome organization and sequence similarities (Zerbini et al. 2017). Begomoviruses have genomes of either a DNA-A (monopartite) or DNA-A and DNA-B (bipartite). The genomes of monopartite begomoviruses are homologous to the DNA-A components of bipartite begomoviruses encodes Rep, TrAp, REn and AC4 protein products in the complementary-sense whereas, $\mathrm{CP}$ and AV2 in the virion-sense. The DNA-B component encodes nuclear shuttle protein (NSP) and movement protein (MP). Most monopartite begomoviruses reported from Asia, Europe, Middle East and Australia have been shown to be associated with betasatellite, which have no or little sequence identity with the helper virus (Briddon and Stanley 2006). The $\beta C 1$ protein of betasatellites have been shown to be involved in symptom determinant, overcoming RNA silencing-based host defenses and movement function. In many cases betasatellites enhance the symptoms of their helper viruses to plants raising viral DNA levels and extending host range (Briddon et al. 2000;

Muhammad Shafiq Shahid

mshahid@squ.edu.om

1 Agricultural Research Education and Extension Organization (AREEO), Iranian Research Institute of Plant Protection, Tehran, Iran

2 Department of Plant Sciences, College of Agricultural and Marine Sciences, Sultan Qaboos University, Al-Khod 123, Muscat, Oman
Saunders et al. 2000). Papaya (Carica papaya) belonging to the Caricaceae family is a dicot woody plant, native to Mexico, America (Central and South) but now adapted in nearly all tropical regions. Different begomovirus species have been reported to infect papaya in Pakistan (Nadeem et al. 1997), Taiwan (Chang et al. 2003), China (Shen et al. 2014), India (Saxena et al. 1998, Sing-Pant et al. 2012; Varun and Saxena 2018; Nehra et al. 2019), Nepal (Shahid et al. 2013), Iran (Bananej et al. 2016), Bangladesh (Hamim et al. 2019) and Oman (Khan et al. 2014). Similarly, association with betasatellites has also been reported in papaya leaf curl disease (PLCD), for example, papaya leaf curl betasatellite, croton yellow vein mosaic betasatellite (Singh-Pant et al. 2012) and tomato leaf curl Java betasatellite (Shahid et al. 2014). During a survey in Feb-2010, leaf samples of four papaya plants exhibiting yellowing and leaf curling symptoms typical of begomovirus infection (Fig. 1) and two apparently healthy were collected from two farms approximately seven kilometers apart in Bahu-Kalat, Baluchestan province, Iran. The DNA extracts were obtained using a CTAB method (Porebski et al. 1997). Initial detection of begomovirus was confirmed for all samples using PCR with a set of diagnostic primers AC1048/ AV494 amplifying 550nt of the coat protein gene (Wyatt and Brown 1996). Rolling circle amplification (RCA) using $\varphi 29$ polymerase (GE Healthcare Limited, UK) was employed and full-length begomovirus $(\sim 2.7 \mathrm{~kb})$ was obtained after digestion of RCA products with BamHI restriction enzyme. The sequences of two potentially full-length clones, of 2,763 and 2,765 nt, were obtained from papaya plants, respectively which were deposited in GenBank (acc.no. MN328257-58) 
Fig. 1 Carica papaya plant showing severe leaf curling and stunting symptoms infected by cotton leaf curl Gezira virus and associated tomato leaf curl betasatellite

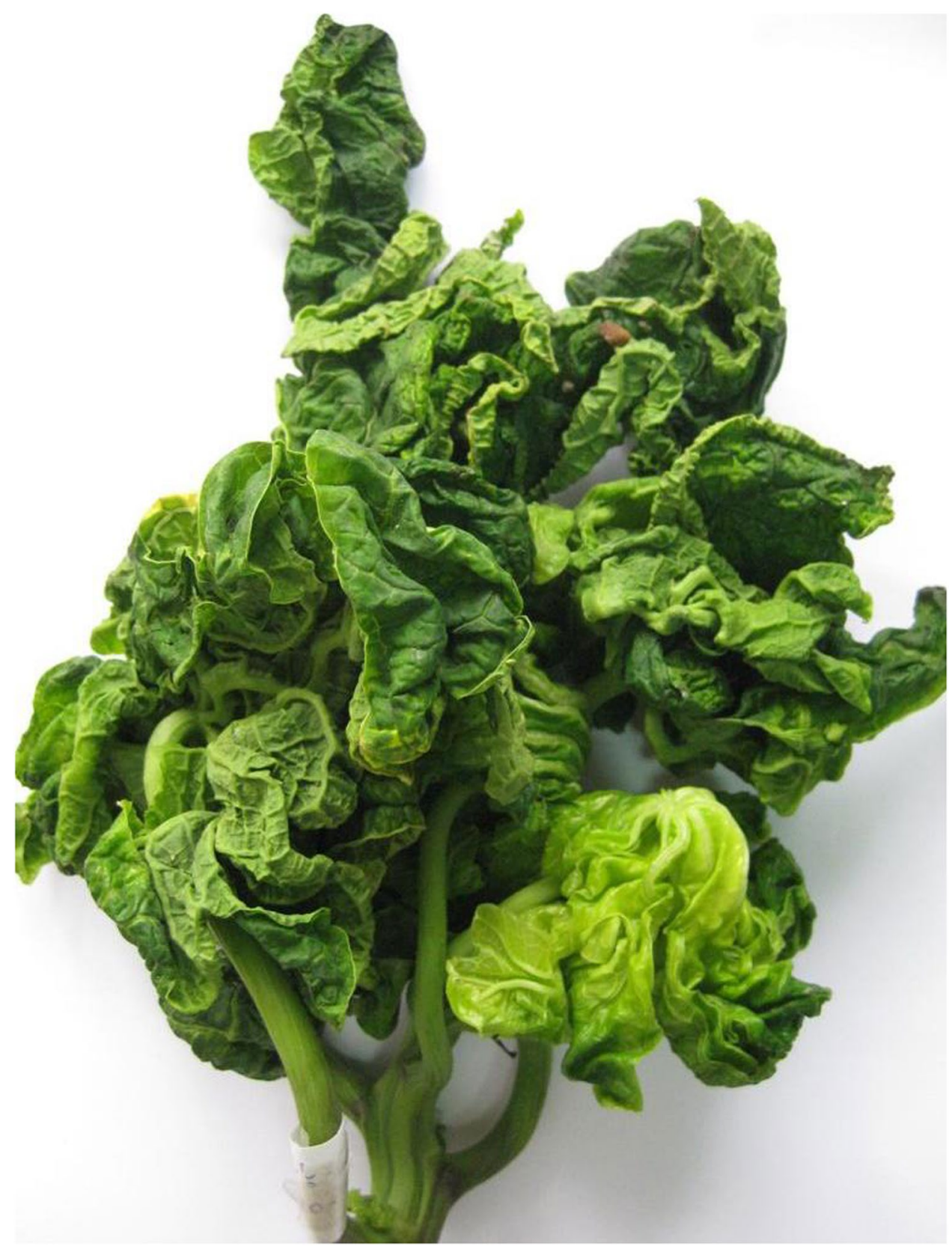

(Supplementary table 1). Pairwise nt comparisons using the SDT v1.2 (Muhire et al. 2014) indicated that these sequences exhibited $99.5 \%$ nucleotide (nt) identity with each other and have the highest levels of identity (99.8\%) to an isolated of the "Egypt" strain of cotton leaf curl Gezira virus (CLCuGeVEG[PK:Sin:NT7:05]; FR751143) identified in cotton leaf curl disease affected cotton in Pakistan (Tahir et al. 2011). In Phylogenetic analysis virus sequences grouped with CLCuGV (Egyptian strains) (Fig. 2a). According to the applicable species segregation criteria (Brown et al. 2015), the virus isolates identified from papaya is the isolates of Egypt strain of CLCuGeV. The associated betasatellite $(\sim 1.4 \mathrm{~kb})$ was obtained using abutting primers SAT101/SAT102 (Shahid et al. 2017) and sequences are available in GenBank (acc no. MN328259-61). Analysis of the betasatellite showed them to have a structure typical of betasatellites, consisting of a satellite conserved region, an A-rich sequence, and a single conserved ORF in the complementary-sense (the $\beta \mathrm{C} 1$ gene; Briddon et al. 2003). Blast and STD analysis showed that these sequences share 95.6 to $97.6 \%$ nt identity with each other and showed highest $95.3 \%$ nt identity with ToLCB reported from chilli (MG587934-5) from Pakistan. Based on the species demarcation criteria set for betasatellites (Adams et al. 2017), the betasatellites clones are isolates of 
(a)

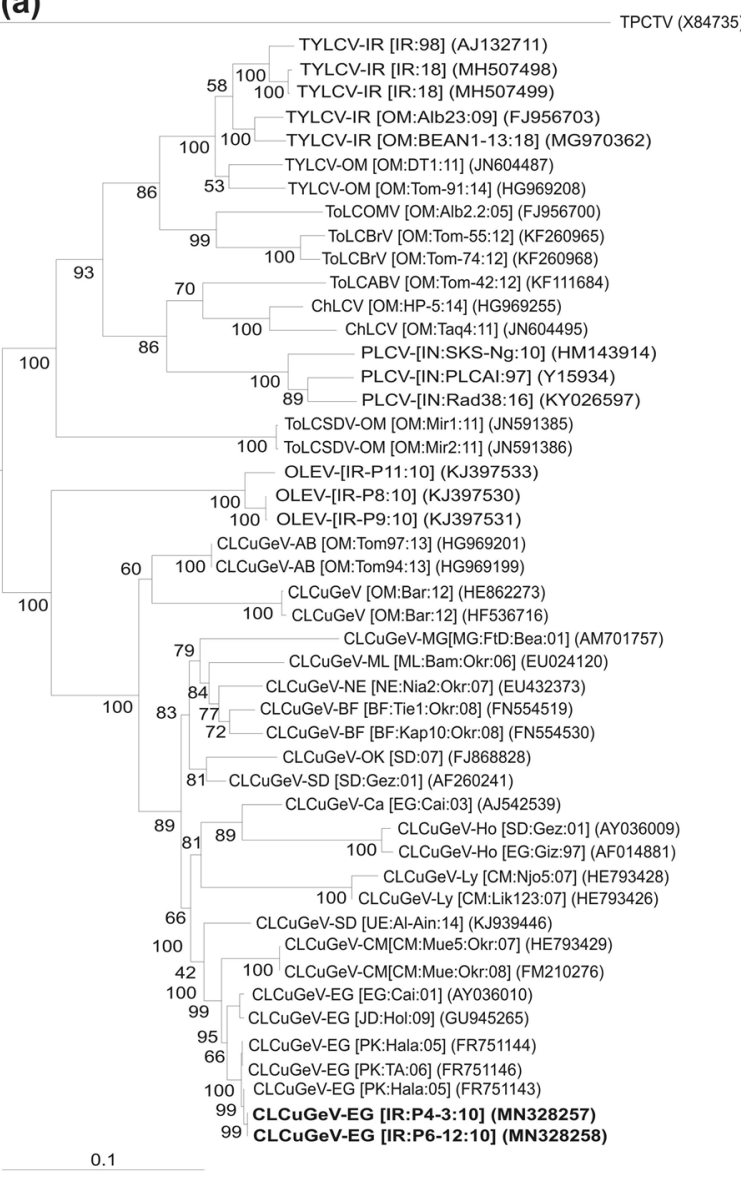

Fig. 2 Phylogenetic dendrograms were produced using Mega7 based upon alignments of the complete nucleotide sequences of the CLCuGV (a) and ToLCB (b). Vertical branches are arbitrary, horizontal branches are proportional to calculate mutation distances. Values at nodes indicate percentage bootstrap values (1000 repli-

ToLCB. This conclusion was supported by a phylogenetic tree showing the sequences isolated from papaya to cluster with previously characterized ToLCB (Fig. 2b). We identified a begomovirus associated with a betasatellite molecule infecting papaya. Normally, $\mathrm{CLCuGeV}$ is known to infect malvaceous plant as cotton and okra (Tahir et al. 2011). Apparently the begomoviruses originated from Middle east and sub-continent are restricted due to geographical barriers. However, there is strong evidence for spread of begomoviruses to westwards. Tomato leaf curl Palampur virus and tomato leaf curl New Dehli virus reported from sub-continent and has spread to Iran and Spain, respectively (Juárez et al. 2014; Zaidi et al. 2017). Surprisingly, CLCuGeV along with alphasatellite and a defective betasatellite complex has been reported recently to infect okra in Southern Texas, USA (Villegas et al. 2019). To date only one earlier study has shown that Okra enation leaf curl virus has been identified from papaya plant. The results of this study show the first association of $\mathrm{CLCuGeV}$ with (b)

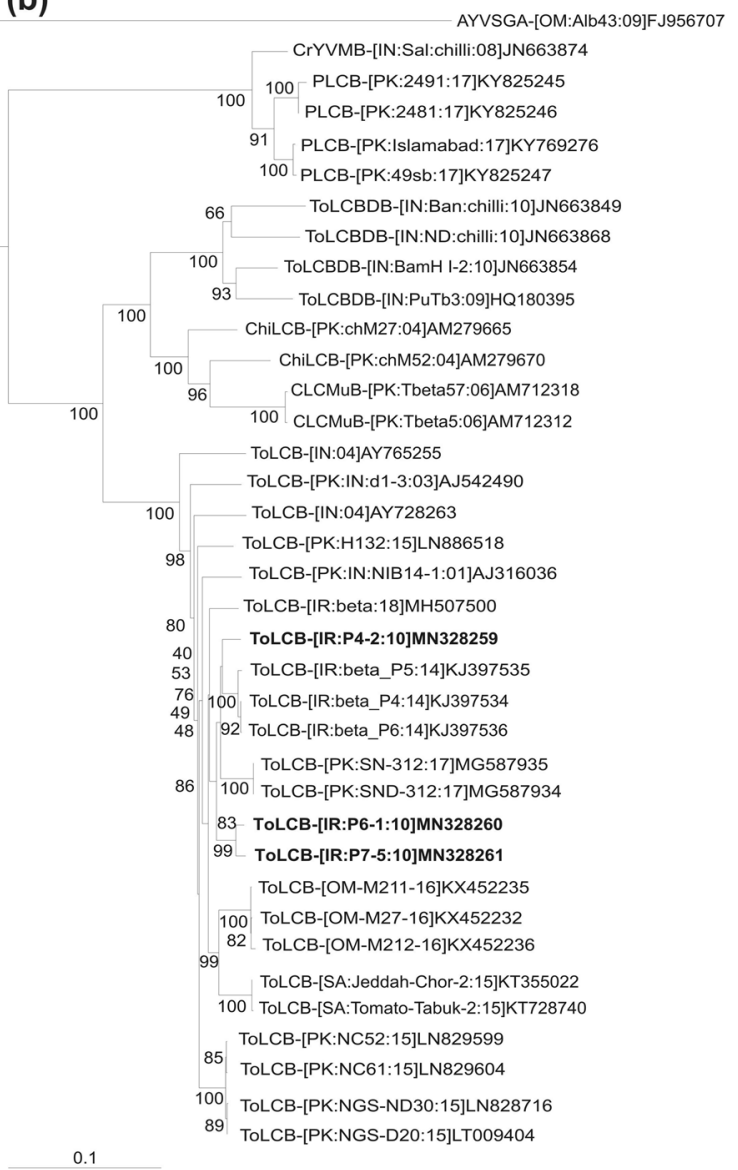

cates). The virus and betasatellite trees were arbitrarily rooted on the sequence of Tomato pseudo-curly top virus (TPCTV) and Ageratum yellow vein Singapore alphasatellite (AYVSGA) respectively. The sequences originating from Carica papaya are indicated by bold text in each case

ToLCB in PLCD and further studies will be required to assess pathogenicity as well as geographic incidence of $\mathrm{CLCuGeV}$ and ToLCB in Iran.

Supplementary information The online version contains supplementary material available at https://doi.org/10.1007/s13314-021-00417-z.

Acknowledgements The authors are grateful to the Dr. Bruno Gronenborn "for critical review the manuscript".

Funding This study was supported by the Iranian Research Institute of Plant Protection (IRIPP), Agriculture Research, Education, and Extension Organization (AREEO), Tehran, Iran (Grant Code: 2-16-16-94116).

\section{Compliance with ethical standards}

Conflict of interest The authors declare that they have no conflict of interest. 


\section{References}

Adams MJ et al (2017) Changes to taxonomy and the International Code of Virus Classification and Nomenclature ratified by the International Committee on Taxonomy of Viruses. Arch Virol 162:2505-2538

Bananej K, Kraberger S, Varsani A (2016) Okra enation leaf curl virus in papaya from Iran displaying severe leaf curl symptoms. J Plant Pathol 98:637-639

Briddon RW, Stanley J (2006) Sub-viral agents associated with plant single-stranded DNA viruses. Virology 344:198-210

Briddon RW, Mansoor S, Bedford ID, Pinner MS, Markham PG (2000) Clones of cotton leaf curl geminivirus induces symptoms atypical of cotton leaf curl disease. Virus Genes 20:17-24

Briddon RW, Bull SE, Amin I, Idris AM, Mansoor S, Bedford ID, Dhawan P, Rishi N, Siwatch SS, Abdel-Salam AM, Brown JK, Zafar Y, Markham PG (2003) Diversity of DNA $\beta$ : a satellite molecule associated with some monopartite begomoviruses. Virology 312:106-121

Brown JK, Zerbini FM, Navas-Castillo J, Moriones E, Ramos-Sobrinho R, Silva JF, Fiallo-Olivé E, Briddon RW, Hernández-Zepeda C, Idris A, Malathi VG, Martin DP, Rivera-Bustamante R, Ueda S, Varsani A (2015) Revision of Begomovirus taxonomy based on pairwise sequence comparisons. Arch Virol 160:1593-1619

Chang LS, Lee YS, Su HJ, Hung TH (2003) First report of Papaya leaf curl virus infecting papaya plants in Taiwan. Plant Dis 87:204

Hamim I, Borth WB, Melzer MJ, Suzuki JY, Wall MM, Hu JS (2019) Occurrence of tomato leaf curl Bangladesh virus and associated subviral DNA molecules in papaya in Bangladesh: molecular detection and characterization. Arch Virol 164:1661-1665

Juárez M, Tovar R, Fiallo-Olivé E, Aranda MA, Gosálvez B, Castillo P, Moriones E, Navas-Castillo J (2014) First detection of Tomato leaf curl New Delhi virus infecting zucchini in Spain. Plant Dis 98:857-857

Khan AJ, Mansoor M, Briddon RW (2014) Oman: a case for a sink of begomoviruses of geographically diverse origins. Trends Plant Sci 19:67-70

Muhire BM, Varsani A, Martin DP (2014) SDT: A virus classification tool based on pairwise sequence alignment and identity calculation. PLoS One 9:e108277

Nadeem A, Mehmood T, Tahir M, Khalid S, Xiong Z (1997) First report of papaya leaf curl disease in Pakistan. Plant Dis 81:1333

Nehra C, Marwal A, Verma RK, Mishra M, Sharma P, Gaur RK (2019) Papaya yellow leaf curl virus: A newly identified begomovirus infecting Carica papaya L. from the Indian Subcontinent. J Hortic Sci Biotech 94:475-480

Porebski S, Bailey LG, Baum BR (1997) Modification of a CTAB DNA extraction protocol for plants containing high polysaccharide and polyphenol components. Plant Mol Biol Rep 15:8-15
Saunders K, Bedford ID, Briddon RW, Markham PG, Wong SM, Stanley J (2000) A unique virus complex causes Ageratum yellow vein disease. PNAS, USA 97:6890-6895

Saxena S, Hallan V, Singh BP, Sane PV (1998) Leaf curl disease of Carica papaya from India may be caused by a bipartite geminivirus. Plant Dis 82:126

Shen W, Tuo D, Yang Y, Yan P, Li X, Zhou P (2014) First report of Ageratum yellow vein virus associated with a new betasatellite infecting Carica papaya in China. J of Plant Pathol 96:603-611

Shahid MS, Yoshida S, Khatri-Chhetri GB, Briddon RW, Natsuaki KT (2013) Complete nucleotide sequence of a monopartite begomovirus and associated satellites infecting Carica papaya in Nepal. Virus Genes 46:581-584

Shahid MS, Ikegami M, Waheed A, Briddon RW, Natsuaki KT (2014) Association of an alphasatellite with tomato yellow leaf curl virus and ageratum yellow vein virus in Japan is suggestive of a recent introduction. Viruses 6:189-200

Shahid MS, Al-Sadi AM, Briddon RW (2017) First Report of Chilli leaf curl virus and Tomato leaf curl betasatellite Infecting watermelon (Citrullus lanatus) in Oman. Plant Dis 101:1063-1063

Singh-Pant P, Pant P, Mukherjee S, Mazumdar-Leighton S (2012) Spatial and temporal diversity of begomoviral complexes in papayas with leaf curl disease. Arch Virol 157:1217-1232

Tahir MN, Amin I, Briddon RW, Mansoor S (2011) The merging of two dynasties - identification of an African cotton leaf curl disease-associated begomovirus with cotton in Pakistan. PLoS One 6:e20366

Varun P, Saxena, S (2018) Association of tomato leaf curl Gujarat virus and tomato leaf curl Bangladesh betasatellite on papaya showing typical leaf curl symptoms in North India. Biotech8 243. https://doi.org/10.1007/s13205-018-1254-7

Villegas C, Ramos-Sobrinho R, Jifon J, Keith C, Al Rwahnih M, Sétamou M, Brown JK, Alabi O (2019) First report of cotton leaf curl Gezira virus and its associated alphasatellite and betasatellite from disease affected okra plants in the united states. Plant Dis 103:3291-3291

Wyatt SD, Brown JK (1996) Detection of subgroup III geminivirus isolates in leaf extracts by degenerate primers and polymerase chain reaction. Phytopathol 86:1288-1293

Zaidi SS, Martin DP, Amin I, Farooq M, Mansoor S (2017) Tomato leaf curl New Delhi virus: a widespread bipartite begomovirus in the territory of monopartite begomoviruses. Mol Plant Pathol 18: 901-11

Zerbini FM, Briddon RW, Idris A, Martin DP, Moriones E, NavasCastillo J, Rivera-Bustamante R, Varsani A, Consortium IR (2017) ICTV Virus Taxonomy Profile: Geminiviridae. J Gen Virol 98:131-133 